\title{
PENGARUH MODEL PEMBELAJARAN KOOPERATIF TIPE TAI (TEAM ASSISTED INDIVIDUALIZATION) TERHADAP HASIL BELAJAR SISWA PADA MATA PELAJARAN EKONOMI DI SMA NEGERI 1 BANYUASIN 1
}

\author{
Oleh: Nur Agung Dinarto \\ (UNIVERSITAS PGRI PALEMBANG)
}

nuragungdinar@gmail.com

\begin{abstract}
Abstrak-Tujuan penelitian ini adalah untuk mengetahui Pengaruh Model Pembelajaran Kooperatif Tipe TAI (Team Assisted Individualization) Terhadap Hasil Belajar Siswa pada Mata Pelajaran Ekonomi di SMA Negeri 1 Banyuasin 1. Metode penelitian yang digunakan adalah metode eksperimen. Teknik pengumpulan data yang digunakan adalah dokumentasi dan tes. Populasi dalam penelitian ini berjumlah 107 siswa, sedangkan sampel dalam penelitian ini berjumlah 71 siswa. Diketahui hasil belajar siswa kelas eksperimen nilai tertinggi adalah 100 dan terendah 60 dengan rata-rata 80,92, sedangkan kelas kontrol nilai tertinggi adalah 80 dan terendah 40 dengan rata-rata 61,56. Hasil penelitian menunjukkan bahwa $t_{\text {hitung }}=6,656>t_{\text {tabel }}=1,994$, maka tolak Ho terima $H \alpha$ dengan demikian terdapat pengaruh yang signifikan antara model pembelajaran kooperatif tipe TAI (Team Assisted Individualization) terhadap hasil belajar siswa pada pada mata pelajaran ekonomi di SMA Negeri 1 Banyuasin 1. Besarnya interpretasi pengaruh adalah sebesar $57,71 \%$ sedangkan sisanya sebesar 42,29\% dipengaruhi faktor lain.
\end{abstract}

KataKunci: Model pembelajaran, kooperatif tipe Team Assisted Individualization, Hasil belajar

\begin{abstract}
The purpose of this study was to determine the effect of Cooperative Learning Type TAI (Team Assisted Individualization) Model on Student Learning Outcomes in Economic Subjects in State Senior High School of Banyuasin 1. The research method used was the experimental method. Data collection techniques used are documentation and tests. The population in this study amounted to 107 students, while the sample in this study amounted to 71 students. It is known that the results of the experimental class students' highest score is 100 and the lowest 60 with an average of 80.92, while the highest control class is 80 and the lowest is 40 with an average of 61.56. The results showed that tcount $=6.656>t$ table $=$ 1.994, then reject Ho accept $H \alpha$ thus there is a significant effect between cooperative learning model type TAI (Team Assisted Individualization) on student learning outcomes on economic subjects in State Senior High School of Banyuasin 1. The magnitude of the interpretation of influence is $57.71 \%$ while the remaining $42.29 \%$ is influenced by other factors.
\end{abstract}

Keywords: Cooperative Learning, Type Team Assisted Individualization, Learning outcomes 


\section{PENDAHULUAN}

Sekolah merupakan salah satu faktor yang mempengaruhi kepribadian dan pembentukan konsep diri anak. Telah diakui dari berbagai pihak tentang peranan sekolah bagaimana sekolah ikut membina anak tentang kecerdasan, sikap, minat dan sebagainya. Sekolah juga merupakan lembaga tempat anak didik memperoleh pendidikan dan pelajaran yang diberikan oleh guru. Sekolah mempersiapkan anak didik memperoleh ilmu pengetahuan, keterampilan, budi pekerti dan meningkatkan ketakwaan kepada Tuhan Yang Maha Esa agar selanjutnya mampu membekali diri menuju kearah pendidikan yang lebih tinggi sebagai bekal hidup di masyarakat. Sekolah menjadi salah satu tempat untuk mendidik dengan memberikan ilmu yang diberikan agar mereka mampu mengembangkan potensi seorang anak sebagai bekal menghadapi tantangan zaman tersebut dan juga untuk mencapai hasil yang semaksimal mungkin dalam proses pembelajaran agar mampu bersaing di dunia kerja nantinya.

Proses belajar mengajar merupakan inti dari kegiatan pendidikan di sekolah. Agar tujuan pendidikan dan pembelajaran berjalan dengan benar, maka perlu pengadministrasian kegiatankegiatan belajar mengajar. Tugas guru sebagai pendidik, yaitu menguasai dan mengembangkan materi pembelajaran, merencanakan dan menyiapkan pelajaran setiap hari, mengontrol dan mengevakuasi aktivitas belajar siswa khususnya dalam pembelajaran ekonomi.

Dalam pembelajaran ekonomi, diharapkan seorang guru memiliki peran penting dalam menyampaikan informasi, melatih keterampilan dan membimbing belajar siswa sehingga para guru dituntut memiliki kualifikasi dan kompetensi tertentu, agar proses belajar dan pembelajaran yang tepat akan menjadikan siswa mudah dalam menerima dan mengolah informasi yang disampaikan oleh guru.

Model pembelajaran terus berkembang sebagai usaha untuk meningkatkan kualitas pendidikan dan kualitas pelajaran. Kemampuan guru dalam merancang pembelajaran yang mampu mengoptimalkan hasil belajar siswa merupakan kunci tercapainya tujuan pembelajaran. Model pembelajaran merupakan istilah yang digunakan untuk menggambarkan penyelengaraan proses belajar mengajar dari awal sampai akhir. Model pembelajaran merupakan sebuah rencana atau pola yang mengorganisasi pembelajaran dalam kelas dan menunjukkan cara penggunaan materi pembelajaran. Model pembelajaran adalah cara-cara atau teknik penyajian bahan ajar yang akan digunakan oleh guru pada saat menyajikan bahan pelajaran, baik secara individual maupun secara kelompok. Model pembelajaran 
dapat dijadikan pola pilihan, artinya para guru boleh memilih model pembelajaran yang sesuai dan efisien untuk mencapai tujuan pendidikan. Tujuan pembelajaran dapat dicapai dengan optimal diperlukan berbagai model pembelajaran.

Dalam penerapannya, banyak model pembelajaran yang menekankan pada keaktifan siswa di dalam proses pembelajaran. Salah satu model pembelajaran yang menekankan keaktifan siswa diantaranya adalah model pembelajaran kooperatif tipe TAI (Team Assisted Individualization). Model pembelajaran kooperatif tipe TAI (Team Assisted Individualization) adalah bantuan individual dalam kelompok (BIDAK) dengan karakteristik bahwa tanggung jawab belajar adalah pada siswa (Ngalimun, 2017:337). Model pembelajaran tipe TAI (Team Assisted Individualization) ini merupakan salah satu tipe dari model pembelajaran kooperatif dan dikembangkan oleh Robert Slavin. Dan model pembelajaran ini memiliki dasar pemikiran yaitu untuk mengadaptasi pembelajaran terhadap perbedaaan individual berkaitan dengan kemampuan maupun pencapaian prestasi siswa.

Hasil belajar adalah tingkat kemampuan siswa setelah mengalami proses belajar dan menunjukkan prestasi belajar siswa secara keseluruhan yang menjadi indikator kompetensi dasar dan derajat perubahan perilaku yang bersangkutan. Hasil belajar siswa dapat tercapai, jika siswa telah mengikuti proses belajar mengajar yang di selenggarakan disekolah. Menurut Hamdayana (2016:28) hasil belajar adalah perubahan diri, dari keadaan tidak tahu menjadi tahu, dari tidak melakukan sesuatu menjadi melakukan sesuatu, dari tidak mampu melakukan sesuatu menjadi mampu melakukan sesuatu.

Belajar sangat erat hubungannya dengan hasil belajar. Karena hasil belajar yang maksimal dapat dicapai oleh peserta didik, maka saat ini diperlukan banyak dikembangkan model pembelajaran yang berguna dan bertujuan untuk mendorong siswa dalam meningkatkan keaktifan setiap siswa dalam proses pembelajaran. Dimana dalam hal ini peneliti menerapkan model pembelajaran kooperatif tipe TAI (Team Assisted Individualization) sebagai model pembelajaran yang digunakan dalam proses mengajar di sekolah untuk meningkatkan hasil belajar siswa khususnya pada mata pelajaran ekonomi.

Berdasarkan observasi awal yang dilakukan oleh peneliti di SMA Negeri 1 Banyuasin 1, peran guru disini masih sangat besar atau guru sebagai sumber pembelajaran dimana guru menyampaikan pembelajaran secara konvensional yaitu sebagian besar disampaikan melalui ceramah. Hasil belajar siswa sudah baik tetapi 
belum optimal, hal ini dapat dilihat dari ketuntasan siswa $60 \%$ sedangkan yang tidak tuntas $40 \%$ yang tidak mencapai kriteria ketuntasan belajar (KKM) yaitu 75 . Masalah ketidak tuntasan belajar siswa tersebut tidak terlepas dari model pembelajaran yang digunakan guru dalam mengajarkan materi, serta dipengaruhi oleh faktor-faktor lain. Berdasarkan latar belakang permasalahan tersebut, peneliti berkeinginan mengadakan penelitian dengan judul: "Pengaruh Model Pembelajaran Kooperatif Tipe TAI (Team Assisted Individualization) Terhadap Hasil Belajar Siswa pada Mata Pelajaran Ekonomi di SMA Negeri 1 Banyuasin 1".

\section{METODE PENELITIAN}

Metode yang digunakan dalam penelitian ini adalah metode eksperimen. "Metode eksperimen dapat diartikan sebagai metode penelitian yang digunakan untuk mencari pengaruh perlakuan tertentu terhadap yang lain dalam kondisi yang terkendalikan" (Sugiyono, 2014:72).

Penelitian ini dilaksanakan di kelas $X$ IPS SMA Negeri 1 Banyuasin 1 yang terletak di Jalan Sepakat RT.11 RW.02 No.96 Kelurahan Mariana Ilir, Kecamatan Banyuasin 1, Kabupaten Banyuasin. Waktu pelaksanaan penelitian ini dilakukan terhitung dari tanggal 15 April sampai dengan 30 Mei 2019 yang meliputi pengumpulan, pengolahan dan analisis data.

Teknik Pengumpulan Data "Teknik pengumpulan data merupakan langkah yang paling utama dalam penelitian, karena tujuan utama dari penelitian adalah mendapatkan teknik pengumpulan data dalam penelitian ini adalah dokumentasi dan tes" (Sugiyono, 2015:308). Jelasnya kedua teknik tersebut dapat diuraikan berikut ini:

1. Dokumentasi

"Dokumentasi adalah catatan peristiwa penting yang sudah berlalu. Dokumen bisa berbentuk tulisan, gambar, atau karya-karya monumental dari seseorang" (Sugiyono, 2011:329). Pada penelitian ini teknik dokumentasi digunakan untuk memperoleh data secara umum yaitu tentang keadaan siswa, hasil belajar siswa, keadaan guru, serta sarana dan prasarana di SMA Negeri 1 Banyuasin 1.

2. Tes

Tes adalah serangkaian pertanyaan atau latihan yang digunakan untuk mengukur keterampilan, pengetahuan, intelegensi, kemampuan, atau bakat yang dimiliki oleh individu atau kelompok (Arikunto, 2013:266). Teknik tes dalam penelitian ini digunakan untuk memperoleh data hasil belajar siswa pada mata pelajaran ekonomi. Tes disajikan 
dan dijawab dalam bentuk Pilihan Ganda setelah proses belajar mengajar selesai.

\section{HASIL DAN PEMBAHASAN}

\section{Hasil Penelitian}

\section{Deskripsi Tempat Penelitian}

SMA Negeri 1 Banyuasin 1 merupakan salah satu Sekolah Menengah Atas Negeri yang ada di Kabupaten Banyuasin yang telah terakreditasi A. Sekolah ini terletak di Jalan Sepakat No.96 RT.11 RW.02 Kelurahan Mariana Ilir, Kecamatan Banyuasin 1, Kabupaten Banyuasin, Provinsi Sumatera Selatan dengan Nomor Pokok Sekolah Nasional (NPSN) 10602504. SMA Negeri 1 Banyuasin 1 ini didirikan pada tanggal 05 Mei 1992 di atas tanah seluas $15000 \mathrm{~m} 2$ dengan SK Pendirian Sekolah 0216/O/1992. Dan Sekolah ini mulai beroperasi pada tanggal 05 Mei 1992 dengan SK Izin Operasional 0216/O/1992.

Proses belajar mengajar di sekolah ini telah menerapkan sistem belajar Full Day dengan menggunakan kurikulum 2013. Selain itu juga, SMA Negeri 1 Banyuasin 1 merupkan sekolah negeri dengan status kepemilikan Pemerintah Daerah.

\section{Deskripsi Pelaksanaan Penelitian Penelitian ini berjudul pengaruh penerapan model pembelajaran kooperatif tipe TAI (Team Assisted Individualization)}

terhadap hasil belajar siswa di SMA Negeri 1 Banyuasin 1. Tujuan dari penlitian ini adalah untuk mengetahui hasil belajar siswa pada mata pelajaran ekonomi di SMA Negeri 1 Banyuasin 1 melalui model pembelajaran kooperatif tipe TAI (Team Assisted Individualization). Sampel dalam penelitian ini terdiri dari dua kelas yaitu kelas X IPS 2 dan X IPS 3, dimana sebagai kelas eksperimen adalah kelas X IPS 2 yang berjumlah 35 siswa dan sebagai kelas kontrol adalah kelas X IPS 3 yang berjumlah 36 siswa.

Dalam pelaksanaan penelitian ini kelas eksperimen diberi perlakuan dengan model pembelajaran kooperatif tipe TAI (Team Assisted Individualization) sedangkan kelas kontrol peneliti mengggunakan model pembelajaran konvensional atau ceramah. Sebelum penelitian ini dilaksanakan, peneliti terlebiih dahulu mempersiapkan Rencana Pelaksanaan Pembelajaran (RPP) untuk kelas eksperimen dan kelas kontrol. Setelah materi manajemen selesai diajarkan atau dibahas, maka selanjutnya akan diadakan tes akhir untuk mengukur hasil belajar siswa, baik kelas eksperimen maupun kelas kontrol. Dan tes yang diberikan adalah berbentuk tes pilihan ganda.

\section{Deskripsi Hasil Belajar Siswa Kelas Eksperimen \\ Berdasarkan analisis data hasil belajar siswa kelas X IPS 2 sebagai kelas eksperimen selama}


proses belajar mengajar di atas, siswa kelas eksperimen dapat dilihat distribusi frekuensi hasil belajar pada tabel dibawah ini:

Tabel 1. Distribusi Frekuensi Hasil Belajar Siswa Kelas Eksperimen

\begin{tabular}{|c|c|c|c|c|}
\hline No. & Interval Penilaian \% & Frekuensi & Persentase & Keterangan \\
\hline 1 & $86-100$ & 9 & $25,71 \%$ & Baik Sekali \\
\hline 2 & $71-85$ & 23 & $65,72 \%$ & Baik \\
\hline 3 & $56-70$ & 3 & $8,57 \%$ & Cukup \\
\hline 4 & $41-55$ & - & - & Kurang \\
\hline 5 & $\leq 40$ & - & - & Kurang Sekali \\
\hline & Jumlah & $\mathbf{3 5}$ & $\mathbf{1 0 0 \%}$ & - \\
\hline
\end{tabular}

Sumber : Pengolahan Data 2019

Berdasarkan tabel diatas, memperoleh nilai hasil belajar pada dapat dilihat bahwa dalam proses kriteria kurang dan sangat kurang. belajar mengajar dengan menggunakan model pembelajaran kooperatif tipe TAI (Team Assisted Individualization), ternyata

\section{Deskripsi Hasil Belajar Siswa Kelas Kontrol}

Berdasarkan analisis data persentase terbesar dari siswa sebesar $65,22 \%$ hasil belajar pada kriteria baik, disusul dengan kriteria baik sekali sebesar $25,71 \%$, sedangkan pada kriteria cukup sebesar $8,57 \%$ dan tidak ada siswa yang

Tabel 2. Distribusi Frekuensi Hasil Belajar Siswa Kelas Kontrol

\begin{tabular}{|c|c|c|c|c|}
\hline No. & Interval Penilaian \% & Frekuensi & Persentase & Keterangan \\
\hline 1 & $86-100$ & - & - & Baik Sekali \\
\hline 2 & $71-85$ & 4 & $11,11 \%$ & Baik \\
\hline 3 & $56-70$ & 24 & $66,67 \%$ & Cukup \\
\hline 4 & $41-55$ & 7 & $19,44 \%$ & Kurang \\
\hline 5 & $\leq 40$ & 1 & $2,78 \%$ & Kurang Sekali \\
\hline & Jumlah & $\mathbf{3 6}$ & $\mathbf{1 0 0 \%}$ & - \\
\hline
\end{tabular}

Sumber : Pengolahan Data 2019

Berdasarkan tabel diatas, konvensional atau ceramah, ternyata dapat dilihat bahwa dalam proses persentase terbesar dari siswa sebesar belajar mengajar dengan $66,67 \%$ hasil belajar pada kriteria menggunakan model pembelajaran cukup, disusul dengan kriteria 
kurang sebesar 19,44\%, dan kriteria baik sebesar 11,11\%, sedangkan pada kriteria kurang sekali sebesar $2,78 \%$ dan tidak ada siswa yang memperoleh nilai hasil belajar pada kriteria sangat baik.

\section{Pengujian Hipotesis}

Dari hasil perhitungan diatas diperoleh harga $t_{\text {hitung }}=6,656>$ dari $\mathrm{t}_{\text {tabel }}=1,994$ berarti tolak Ho dan terima $\mathrm{H} \alpha$ maka hipotesis penelitian berbunyi ada pengaruh yang signifikan model pembelajaran kooperatif tipe TAI (Team Assisted Individualization) terhadap hasil belajar siswa pada mata pelajaran ekonomi di SMA Negeri 1 Banyuasin 1, diterima dengan besar pengaruh $57,71 \%$ sedangkan sisanya sebesar 42,29 dipengaruhi faktor lain.

\section{Pembahasan}

\section{Hasil Penelitian Dikaitkan dengan Kajian Teori}

Berdasarkan hasil analisis di atas, pengaruh hasil belajar tersebut dikarenakan dalam pelaksanaan proses pembelajaran pada kelas eksperimen yang diterapkan model pembelajaran kooperatif tipe TAI (Team Assisted Individualization) siswa diusahakan aktif dalam proses pembelajarannya. Kesan yang dialami oleh siswa lebih mendalam dan tertanam dalam ingatan yang pada akhirnya berdampak pada peningkatan siswa tersebut dalam penguasaan materi yang diberikan.
Sedangkan dalam pelaksanaannya proses pembelajaran yang dilakukan, hal ini pun berdampak pada siswa mengenai penguasaan materi yang diberikan.

Hal tersebut dikarenakan pada model pembelajaran kooperatif tipe TAI (Team Assisted Individualization) siswa berperan aktif dalam pembelajaran, baik dalam menentukan topik permasalahan maupun cara untuk menyelesaikannya. Kesuksesan model pembelajaran model pembelajaran kooperatif tipe TAI (Team Assisted Individualization) juga terbukti pada penelitian ini, ternyata dengan penerapan model pembelajaran model pembelajaran kooperatif tipe TAI (Team Assisted Individualization) siswa dapat lebih aktif dalam proses pembelajaran dan berpengaruh terhadap kesungguhan siswa dalam proses belajar mengajar. Hal ini terlihat rata-rata hasil belajar yang diperoleh siswa melalui tes yang telah diberikan..

Model pembelajaran adalah kerangka konseptual yang menggambarkan prosedur sistematika dalam mengorganisasikan pengalaman belajar untuk mencapai tujuan belajar. Sedangkan model pembelajaran kooperatif tipe TAI (Team Assisted Individualization) adalah model pembelajaran yang menekankan pembelajaran membaca dan menulis secara berkelompok. 
Model pembelajaran kooperatif tipe TAI (Team Assisted Individualization) baik diterapkan pada materi manajemen, karena materi tersebut memberikan kesempatan bagi siswa untuk lebih aktif berdiskusi, mencari informasi dari pengalaman atau kejadian sehari-hari. Sedangkan metode ceramah siswa hanya mendengarkan penjelasan peneliti kemudian mengerjakan tugas yang diberikan oleh peneliti.

Berdasarkan hasil distribusi hasil belajar kelas eksperimen yang memperoleh nilai pada kriteria "Baik Sekali” sebesar 25,71\%, yang memperoleh nilai pada kriteria "Baik" sebesar 65,72\%, yang memperoleh nilai pada kriteria "Cukup" sebesar 8,57\% dan tidak ada yang memperoleh nilai pada kriteria "Kurang" dan "Kurang Sekali". Rata-rata nilai hasil belajar siswa pada kelas eksperimen adalah sebesar 80,92\%. Sedangkan hasil distribusi hasil belajar kelas kontrol yang memperoleh nilai pada kriteria "Baik" sebesar 11,11\%, yang memperoleh nilai pada kriteria "Cukup" sebesar 66,67\%, yang memperoleh nilai pada kriteria "Kurang" sebesar 19,44\%, yang memperoleh nilai pada kriteria "Kurang Sekali" sebesar 2,78\% dan tidak ada yang memperoleh nilai pada kriteria "Baik Sekali". Rata-rata nilai hasil belajar siswa pada kelas eksperimen adalah sebesar $61,56 \%$. Berdasarkan penelitian yang dilakukan peneliti diperoleh nilai $t_{\text {hitung }}=6,656>$ dari $t_{\text {tabel }}=1,994$ berarti tolak Ho dan terima $\mathrm{H} \alpha$ maka hipotesis penelitian berbunyi ada pengaruh yang signifikan model pembelajaran kooperatif tipe TAI (Team Assisted Individualization) terhadap hasil belajar siswa pada mata pelajaran ekonomi di SMA Negeri 1 Banyuasin 1.

\section{Hasil Penelitian Dikaitkan dengan Kajian Penelitian Relevan}

Berdasarkan hal tersebut maka senada dengan pendapat Hengki Ternado (2015) yang menyatakan ada pengaruh penerapan model pembelajaran tipe Team Assisted Individualization) terhadap hasil belajar siswa pada mata pelajaran ekonomi di SMA Gajah Mada 3 Palembang tahun pelajaran 2015/2016. Terbukti dari hasil pengujian hipotesis menunjukkan $\mathrm{t}_{\text {hitung }}=7,40>\mathrm{t}_{\text {tabel }} 2,003$.

Selain itu juga sejalan dengan pendapat Intan Pertiwi (2016) yang menyatakan terdapat pengaruh model Team Assisted Individualization terhadap hasil belajar siswa pada mata pelajaran ekonomi di SMA Negeri 1 Pedamaran Timur tahun pelajaran 2015/2016. Terbukti dari hasil pengujian hipotesis menunjukkan $\mathrm{t}_{\text {hitung }} 11,8$ dengan taraf signifikan 0.05 lebih besar dibandingkan dengan $t_{\text {tabel }} 1,67$ jadi dari hasil perhitungan didapat $\mathrm{t}_{\text {hitung }}=$ $11,8>\mathrm{t}_{\text {tabel }}=1,67$. 
Hasil analisis dalam penelitian ini menunjukkan bahwa terdapat pengaruh model pembelajaran kooperatif tipe TAI (Team Assisted Individualization)terhadap hasil belajar siswa pada mata pelajaran ekonomi di SMA Negeri 1 Banyuasin 1. Hasil perhitungan hasil belajar siswa yang diperoleh dari nilai tes diperoleh nilai tertinggi pada kelas eksperimen yaitu sebesar 100 dan yang terendah 60, diperoleh rata-rata hasil belajar siswa sebesar 80,92. Terdapat 9 siswa dengan persentase $25,71 \%$ pada kriteria "Baik Sekali", 23 siswa dengan persentase $65,72 \%$ pada kriteria "Baik" dan 3 siswa dengan persentase $8,57 \%$ pada kriteria "Cukup". Sedangkan nilai tertinggi pada kelas kontrol yaitu 80 dan yang terendah 40, diperoleh rata-rata sebesar 61,56. Terdapat 4 siswa dengan persentase $11,11 \%$ pada kriteria "Baik", terdapat 24 dengan persentase $66,67 \%$ pada kriteria "Cukup", terdapat 7 siswa dengan persentase 19,44\%pada kriteria "Kurang", dan terdapat 1 siswa dengan persentase $2,78 \%$ pada kriteria "Kurang Sekali".

Penelitian menggunakan rumus uji $\mathrm{t}$ dengan hasil perhitungan diperoleh harga $t_{\text {hitung }}=6,656>$ dari $\mathrm{t}_{\text {tabel }}=1,994$ berarti tolak Ho dan terima $\mathrm{H} \alpha$ maka ada pengaruh yang signifikan model pembelajaran kooperatif tipe TAI (Team Assisted Individualization) terhadap hasil belajar siswa yaitu sebesar $57,71 \%$ sedangkan sisanya sebesar 42,29 dipengaruhi faktor lain.

Dari uraian di atas maka dapat dartikan bahwa meerapkan model pembelajaran kooperatif tipe TAI (Team Assisted Individualization) dapat meningkatkan hasil belajar siswa.

\section{KESIMPULAN DAN SARAN \\ Kesimpulan}

Berdasarkan hasil analisis data mengenai pengaruh model pembelajaran kooperatif tipe TAI (Team Assisted Individualization) terhadap hasil belajar siswa di SMA Negeri 1 Banyuasin 1 disimpulkan sebagai berikut:

1. Berdasarkan analisis data teknik dokumentasi hasil belajar siswa pada mata pelajaran ekonomi materi tentang manajemen kelas eksperimen sebanyak 35 orang siswa dengan jumlah rata-rata hasil belajar sebesar 80,92. Terdapat 9 orang siswa diperoleh persentase sebesar $25,71 \%$ pada kriteria "Baik Sekali", terdapat 23 orang siswa dengen persentase $65,72 \%$ pada kriteria "Baik", dan 3 orang siswa dengan persentase $8,57 \%$ pada kriteria "Cukup". Sedangkan pada kelas kontrol sebanyak 36 orang siswa dengan jumlah rata-rata hasil belajar sebesar 61.56. Terdapat 4 orang siswa diperoleh persentase sebesar $11,11 \%$ pada kriteria 
"Baik", terdapat 24 orang siswa dengen persentase $66,67 \%$ pada kriteria "Cukup", terdapat 7 orang siswa dengan persentase 19,44\% pada kriteria "Kurang", dan 1 orang siswa dengan persentase $2,78 \%$ pada kriteria "Kurang Sekali".

2. Berdasarkan hasil hipotesis yang dilakukan menggunakan uji $\mathrm{t}$ adapun rumus regresi yang digunakan adalah regresi linear sederhana, terdapat pengaruh model pembelajaran kooperatif tipe TAI (Team Assisted Individualization) terhadap hasil belajar siswa di SMA Negeri 1 Banyuasin 1. Hal ini terlihat dari hasil hipotesis yang diperoleh $t_{\text {hitung }}>t_{\text {tabel }}$ atau 6,656 $>1,994$ dan hasil perhitungan koefisien determinasi besar pengaruh model pembelajaran kooperatif tipe TAI (Team Assisted Individualization) terhadap hasil belajar siswa sebesar $57,71 \%$ sedangkan sisanya sebesar 42,29 dipengaruhi faktor lain.

\section{Saran}

Berdasarkan kesimpulan yang telah diuraikan, peneliti memberikan saran sebagai berikut:

1. Bagi guru, khususnya guru mata pelajaran ekonomi model pembelajaran kooperatif tipe TAI (Team Assisted Individualization) agar dapat disajikan alternatif guru dalam kegiatan belajar mengajar sehingga diharapkan dapat meningkatkan hasil belajar siswa.

2. Bagi sekolah, dapat meningkatkan kualitas proses pembelajaran lebih optimal karena model pembelajaran yang diajarkan selama ini belum bervariatif.

3. Bagi siswa, dengan menggunakan model pembelajaran yang diberikan dapat diciptakan situasi belajar yang menarik dan merangsang siswa untuk aktif dalam belajar, sehingga dapat meningkatkan hasil belajar.

4. Bagi kalangan akademis, memberikan sumbangan informasi serta sumber bacaan peneliti yang akan datang.

\section{DAFTAR PUSTAKA}

Alam, S. (2013). Ekonomi Untuk SMA/MA Kelas X. Jakarta: Erlangga

Arikunto, S. (2013). Prosedur Penelitian. Jakarta: Rineka Cipta.

(2014). Manajemen Penelitian. Jakarta: Rineka Cipta.

Asykari, Asep Fauzan. (2016). Pengaruh Model Pembelajaran Kooperatif Tipe Team Assisted Individualization (TAI) Terhadap Hasil Belajar Matematika Siswa di SMP Negeri 5 Muara Enim. Palembang: $\quad$ FKIP Universitas PGRI Palembang. 
Basir, D, dan Amrina, D, E. (2017). Pengantar Metode Penelitian Pendidikan. Palembang: UPT. Penerbit dan Percetakan Universitas Sriwijaya.

Geminastiti, K dan Nurlita, N. (2016). Belajar \& Pembelajaran. Jakarta: Rineka Cipta.

Hamdayama, Jumanta. (2014). Model dan Metode Pembelajaran Kreatif dan Berkarakter. Jakarta: Ghalia Indonesia.

Nazir, M. (2014). Metode Penelitian. Bogor: Ghalia Indonesia.

Ngalimun. (2017). Strategi Pembelajaran Dilengkapi dengan 65 Model Pembelajaran. Yogyakarta: Parama Ilmu.

Pertiwi, Intan. (2016). Pengaruh Model Pembelajaran Team Assisted Individualization (Kombinasi dari Belajar Kooperatif Dengan Belajar Individu) Terhadap Hasil Belajar Siswa pada Mata Pelajaran Ekonomi di SMA Negeri 1 Pedamaran Timur Tahun Pelajaran 2015/2016. Palembang: FKIP Universitas PGRI Palembang.

Purwanto. (2016). Evaluasi Hasil Belajar. Yogyakarta: Pustaka Belajar.

Putri, Riska Indah. (2016). Pengaruh Model Pembelajaran Kooperatif Tipe Team Assisted Individualization (TAI) Terhadap Motivasi Belajar Matematika Siswa SMP Negeri 5 Palembang. Palembang:
Universitas

PGRI

Palembang.

Riduwan. (2013). Belajar Mudah Penelitian. Bandung: Alfabeta.

Shoimin, Aris. (2013). 68 Model Pembelajaran Inovatif dalam Kurikulum 2013. Yogyakarta: Ar-Ruzz Media.

Sianipar, Eduar Muharrim Bona, daan Hidayat, Karyadi. (2016). Statistik Analisis Regresi dan Korelasi. Palembang: Noer Fikri.

Slameto. (2010). Belajar dan FaktorFaktor yang Mempengaruhi. Jakarta: Rineka Cipta.

Sugiyono. (2015). Metode Penelitian Pendidikan Pendekatan, Kualitatif dan $R \& D$. Bandung: Alfabeta. . (2017). Statistik untuk Penelitian. Bandung: Alfabeta.

Suhana, C. (2014). Konsep Strategi Pembelajaran. Bandung: Refika Aditama.

Suprijono, Agus. (2015). Cooperative Learning. Yogyakarta: Pustaka Belajar.

Ternado, Hengki. (2015). Pengaruh Penerapan Model Pembelajaran Kooperatif Tipe Team Assisted Individualization Terhadap Hasil Belajar Siswa Pada Mata Pelajaran Ekonomi di SMA Gajah Mada 3 Palembang Tahun Pelajaran 2015/2016. Palembang: $\quad$ FKIP Universitas PGRI Palembang. 
Tim Penyusun. (2018). Pedoman

Penulisan Skripsi Tahun

Akademik 2018/2019.

Palembang: $\quad$ FKIP

Universitas PGRI

Palembang.

Susanto, Ahmad. (2016). Teori Belajar \& Pembelajaran.

Jakarta: Prenadamedia Group.

Trianto. (2014). Model

Pembelajaran Terpadu

Konsep, Strategi, dan Implementasinya dalam Kurikulum Tingkat Satuan Pendidikan (KTSP). Jakarta: PT. Bumi Aksara

Yani, Serly Dwi. (2013). Pengaruh Model Pembelajaran Kooperatif Tipe Team Assidted Individualization Terhadap Hasil Belajar pada Mata Pelajaran IPS Terpadu (Geografi) Kelas VII di SMP Negeri 7 Palembang Tahun Pelajaran 2012/2013. Palembang: $\quad$ FKIP Universitas PGRI Palembang. 